\title{
Antiviral Potential of Mushrooms in the Light of their Biological Active Compounds
}

\author{
Waill A. Elkhateeb ${ }^{1 *}$, Ghoson M. Daba ${ }^{1}$, Elmahdy M. Elmahdy ${ }^{2}$, Paul W. Thomas ${ }^{3,4}$, Ting-Chi \\ Wen $^{5}$, Mohamed N.F. Shaheen ${ }^{2}$ \\ ${ }^{1}$ Chemistry of Natural and Microbial Products Department, Pharmaceutical Industries Researches Division, \\ National Research Centre, El Buhouth St., Dokki, 12311, Giza, Egypt.
}

${ }^{2}$ Environmental Virology Laboratory, Water Pollution Research Department, Environmental Research Division, National Research Center, El Buhouth St., Dokki, 12311, Giza, Egypt.

${ }^{3}$ Mycorrhizal Systems Ltd, Lancashire, PR25 2SD, UK.

${ }^{4}$ University of Stirling, Stirling, FK9 4LA, UK.

${ }^{5}$ The Engineering Research Center of Southwest Bio-Pharmaceutical Resources, Ministry of Education, Guizhou University, Guiyang 550025, Guizhou Province, China.

*Corresponding Author: Waill A. Elkhateeb, Chemistry of Natural and Microbial Products Department, Pharmaceutical Industries Researches Division, National Research Centre, El Buhouth St., Dokki, 12311, Giza, Egypt.

\begin{abstract}
Life-threaten diseases, especially those caused by viruses, require searching and investigation in order to find potent compounds and drugs. Mushrooms are promising sources of compounds showing bioactive potency whenever tested. This review highlights extracts and compounds originated from mushrooms fruiting bodies and or mycelia. Further studies are encouraged to discover novel potent antiviral compounds/ extracts or evaluate already known compounds extracted from those edible medicinal mushrooms.
\end{abstract}

Keywords: Medicinal Mushrooms, antiviral activities, cordycepin, ganoderic acid

\section{INTRODUCTION}

In contrast to bacterial illness, viral illness cannot be treated or controlled by traditional antibiotics so specific drugs or antiviral agents are urgently needed. Viruses play a major role in serious infections in children and adults and sometimes lead to the need for admission to intensive care units and hospitalization, especially in cases of encephalopathy or severe respiratory distress. Parainfluenza viruses, Influenza, herpes viruses, syncytial respiratory virus, and adenoviruses are the most frequent pathogens of these severe infections [1].

Antiviral properties of mushrooms were evaluated not only for whole extracts but also for some isolated compounds. The fractions and compounds showing antiviral effects were extracted from both fruiting bodies and mycelia. They can inhibit virus replication directly via inhibition of viral enzymes, viral nucleic acids synthesis, or prevention of virus adsorption and uptake into mammalian cells. In addition, they can inhibit virus replication indirectly by stimulation of the immune system by their polysaccharides or other complex molecules $[2,3]$.

Truffles are typical symbiotic ectomycorrhizal mushrooms and thus must grow in association with host plant. On the other hand, the antimicrobial activities of desert ectomycorrhizal Mushrooms (Truffles) have been investigated decades ago by many researchers who studied extracts of Terfezia claveryi which exhibited antiviral activity. $[4,5]$.

Ectomycorrhizal mushrooms (Truffles) contain a variety of biochemical components, including steroids, pheromones, flavonoide, anthocyanine, carotenoide, oligosaccharide and volatile organic compounds such as dimethyl-sulfide and bisulfide, butanedione, butyrate, hexenone, ethyl-, methyland propylphenole and methylthiomethane. Till now, limited studies were conducted on truffles though they represent unexplored sources with potential therapeutic activities due to containing antiviral, antiviral, antioxidant, antimicrobial, hepatoprotective, immune-modulating, anticarcinogenic, antidepr- 
essant and sedative bioactive compounds [6,7]. Truffle extracts showed Antiviral activity as reported by Hussan and Al-Ruqaie, [8].

On the other hand, a study describing the antiviral properties of methanolic extracts and aqueous extracts from other mushroom species such as Boletus edulis Bull. (Boletaceae), Lentinula edodes (Berk.) Pegler (Omphalotaceae), and Pleurotus ostreatus (Jacq.: Fr.) P. Kumm. (Pleurotaceae) against Human herpes virus 1 (HSV-1) showed that the methanolic extracts had lower anti-HSV-1 activity than the aqueous extracts [9]. Amoros et al. [10] tested extracts obtained from the basidiocarps of 121 Basidiomycota mushroom species as anti-HSV (types 1 and 2), anti-vesicular stomatitis virus, and antipoliovirus. The study reported that $11 \%$ of these extracts inhibited one or more than one virus, with more active species belonging to the Cortinariaceae and Tricholomataceae families than to the Boletaceae and Russulaceae families. Dichloromethane and Methanol extracts prepared from 57 types of wood-decaying fungi were tested for the ability to inhibit HIV-1 reverse-transcriptase enzyme in vitro [11]. The results demonstrated that the methanolic extracts inhibited the reverse transcriptase activity more strongly than the dichloromethane extracts where Poria monticola Murrill (Polyporaceae) and Laetiporus sulphureus (Bull.) Murrill (Fomitopsidaceae) were the most active species [11]. Lee et al., [12] reported that A hot water extract prepared from Porodaedalea pini (synonym: Phellinus pini; Hymenochaetaceae) basidiocarps showed strong inhibitory effect against Coxsackievirus B3 (CVB3) through preventing its plaques formation on HeLa cell lines. An aqueous extract obtained from Phellinus igniarius was showed also antiviral activities against influenza virus (Types A and B), including H1N1 and human H3N2 [13].

Ganodermadiol, applanoxidic acid G triterpenoids, and lucidadiol isolated from Ganoderma pfeifferi Bres. (Ganodermataceae) and other Ganoderma species showed antiviral activities against influenza virus type A in vitro, showing half-maximal inhibitory concentrations [IC50] of 0.22, 0.19, and 0.22 $\mathrm{mmol} / \mathrm{L}$, respectively, in Madin-Darby canine kidney cell lines [14]. Also, ganodermadiol showed activities against lip exanthemas and other signs caused by HSV-1, with an IC50 value equal to 0.068 $\mathrm{mmol} / \mathrm{L}$ in Vero cell lines [14]. Antiviral effects of aqueous extracts prepared from mycelia of 11 Basidiomycota species were tested against avian influenza and human influenza A viruses. In those studies, the following fungal species were well identified as potential sources of antiviral agents: (Polyporaceae), Ischnoderma benzoinum (Wahlenb.) P. Karst., Fomitopsis officinalis (Vill.) Bondartsev \& Singer (synonym: Laricifomes officinalis; Daedaleopsis confragosa (Bolton) J. Schröt., Cerioporus mollis (Sommerf.) Zmitr. \& Kovalenko (synonym: Datronia mollis; Fomitopsidaceae) Lenzites betulina (L.) Fr., Trametes gibbosa (Pers.) Fr., and T. versicolor (L.) Lloyd (Polyporaceae) $[15,16]$.

Polysaccharide fractions, as well as ethanol and aqueous extracts of Lentinula edodes (Shiitake) exhibited antiviral activity against bovine herpesvirus 1 and poliovirus 1 and replication, and researchers have documented that extracts activities on both virus strains are found at the time replication begins [17]. Agrocybone, which is an individual illudane-illudane bis-sesquiterpene, prepared from Cyclocybe salicaceicola Vizzini (synonym: Agrocybe salicaceicola; Agaricaceae) showed weak antiviral effects against respiratory syncytial virus, with an IC50 of $100 \mu \mathrm{mol} / \mathrm{L}$ [18].

Extracts and total polysaccharide fractions prepared from aqueous extracts of mushrooms belonging to the genera Lentinus, Ganoderma, Daedaleopsis, Pleurotus, Trametes, Inonotus, and Laetiporus showed fully suppressed infectious activity of West Nile virus. In addition, some fungal compounds can show inhibitory activities on human immunodeficiency virus (HIV). It has been reported that PSP from Trametes versicolor and polysaccharides from PSK krestin can inhibit HIV-1 replication in vitro. They show immunostimulatory effect, krestin provides support to the killer cells of the immune system, and the polysaccharide-protein complex inhibiting HIV reverse transcriptase activity and the attachment of HIV-1 gp120 to CD4 surface receptor [11, 19, 20, 21]. Furthermore, a sample of melanin $(\mathrm{SI}=12.5)$ obtained from I. obliquus exerted activity against vaccinia virus. Also, extracts from larch polypore (SI $=2)$ and Chaga $(\mathrm{SI}=2)$ possessed certain antiviral potential [16]. Additional studies on chemical metabolites from fungi (Inonotus obliquus) that inhibit the replication of VARV can detect compounds/fractions with various mechanisms of action, which is relevant for the therapeutic drug development against smallpox infections. [22].

\section{EXAMPLES OF SOME COMPOUNDS WITH POTENT ANTIVIRAL ACTIVITIES}

\subsection{Cordycepin and its Analogs}

Cordycepin (also named 3'-deoxyadenosine) is a purine nucleoside that differs in structure from adenosine in the absence of oxygen atom in the $3^{\prime}$ position of its ribose moiety [23]. Cordycepin was 
originally isolated from the medicinal mushroom Cordyceps militaris [24], but currently it can be produced synthetically due to its potent biologically active properties such as anticancer, antifungal, inhibition of platelet aggregation, and antiviral activities [25-27]. Generally, the action mechanisms of cordycepin is still under investigation, but some studies have explained those activities in relation to its ability to inhibit several protein kinases $[\mathbf{2 8}, \mathbf{2 9}]$.

The antiviral activity of cordycepin has been previously reported against many viruses such as inhibiting influenza viral genome replication [30, 31], inhibiting HIV-1 reverse transcriptase [32], murine leukemia virus and Epstein-Barr virus (EBV) $[33,34]$, inhibiting rota-virus through stimulating the host induced Type I Interferon response in cells [35], in addition to many plant viruses [36].

\subsection{Ganoderic Acids}

Ganoderic acids are the bioactive Triterpenes produced by Ganoderma species [37]. Some of the reported Ganodermic acids are A, AM1, B, $\beta$, C1, C2,C6, D, Df, DM, E, F, G, H,J,K, Mc, Me, Nf, Mk, N, P, R, S, Sz,T, TR,TQ, X, and Y[37]. Studies on ganoderic acids revealed that they exhibit various biological activities such as anti-thrombosis [38], anti-tumor [39], and neuroprotective activities [40]. Moreover, ganoderic acids can selectively inhibit the activities of eukaryotic DNA polymerase [41]. One of the promising activities exerted by ganoderic acids is their antiviral activities against many viruses such as HIV-1 [42]. Ganoderic acid originated from Ganoderma lucidum suppressed hepatitis $B$ virus replication $[43]$.

\subsection{Future Trends}

Mushrooms are functional food and are rich source of assortment of bioactive compounds that offer great therapeutic potential for the prevention and control of several diseases $[\mathbf{3}, \mathbf{4 4}]$. Hence, isolation and identification of bioactive compounds from mushrooms crude extracts are required in order to specify which compound is responsible of the observed antiviral activity. Optimization of submerged culture conditions for mushrooms mycelial growth as well as strain improvement by genetic manipulation should be applied on large scale in order to overproduce the desired compounds. Further research and clinical trials have to be carried out to validate mushrooms as source of bioactive molecules with potential antiviral application.

\section{CONCLUSION}

In conclusion, Studies from different countries have shown that polysaccharides, as well as other fungal compounds (nucleosides, proteins, terpenoids, glycoproteins, etc.) exert antiviral effect against many viruses pathogenic for humans such as orthopoxviruses, herpes, hepatitis viruses, West Nile, human immunodeficiency, and influenza. Biologically active compounds prepared from the same fungal species can show antiviral activities against different viral pathogens.

\section{REFERENCES}

[1] Diaz A, Zaragoza R, Granada R, Salavert M. Acute viral infections in immunocompetent patients. Med Intensiva. 2011; 35(3): 179-185.

[2] Brandt CR, Piraino F. Mushroom antivirals. Recent Res Dev Antimicrob Agents Chemother. 2000; 4: 1126.

[3] Elkhateeb WA, Daba GM, Sheir D, Negm El-Dein A, Walid Fayad, ELmahdy, ME, Shaheen, MNF, Paul W. Thomas, Ting-Chi Wen. GC-Mass analysis and In vitro hypocholesterolemic, anti- rotavirus, anti-human colon carcinoma activities of the crude extract of a Japanese Ganoderma Sp. Egyptian pharmaceutical journal. 2019; 18(2).

[4] Al-Marzooky MA. Truffles in eye disease, in Proceedings of the International Islamic Medicine, Kuwait. 1981; 353-357.

[5] Hussain G, Al-Ruqaie IM. Occurrence, chemical composition and nutritional value of truffles: an overview, Pakistan Journal of Biological Sciences. 1999; 2(2): 510-514.

[6] Hannan MA, Al-Dakan AA, Aboul-Enein HY, Al-Othaimeen AA. Mutagenic and antimutagenic factor(s) extracted from a desert mushroom using different solvents. Mutagenesis. 1989; 4(2): 111-114.

[7] Gajos M, Ryszka F, Geistlinger J. The therapeutic potential of truffle fungi: a patent survey. Acta Mycologica. 2014; 49(2).

[8] Hussan G, Al-Ruqaie IM. Occurrence in chemical composition, and nutritional value of truffles: overview. Pak J Biological Science. 1999; 2(2): 510514. 
[9] Santoyo S, Ramirez-Anguiano AC, Aldars-Garcia L, Reglero G, Soler-Rivas C. Antiviral activities of Boletus edulis, Pleurotus ostreatus and Lentinus edodes extracts and polysaccharide fractions against Herpes simplex virus type 1. J Food Nutr Res. 2012; 51(4): 225-35.

[10] Amoros M, Boustie J, PY ML, Herve V, Robin V, Girre L. Antiviral activity of Homobasidiomycetes: evaluation of 121 Basidiomycetes extracts on four viruses. Int J Pharmacogn. 1997; 35(4): 255-60.

[11] Mlinaric A, Kac J, Pohleven F. Screening of Selected Wood-Damaging Fungi for the HIV-1 Reverse Transcriptase Inhibitors. Acta. Pharmacology. 2005; 55: 69-79.

[12] Lee SM, Kim S-M, Lee Y-H, Kim WJ, Na Y-S, Kim HG, Nam J-H, Shin HD, Kwon DH, Park YI. Antiviral activity of hotwater extract and its ethanol precipitate of Phellinus pini fruiting body. Korean J Microbiol Biotechnology. 2009; 37(1): 33-41.

[13] Lee S, Kim JI, Heo J, Lee I, Park S, Hwang MW, Bae JY, Park MS, Park HJ, Park MS. The anti-Influenza virus effect of Phellinus igniarius extract. J Microbiology. 2013; 5(5): 676-81.

[14] Mothana RA, Awadh NA, Jansen R, Wegner U, Mentel R, Lindequist U. Antiviral lanostanoid triterpenes from the fungus Ganoderma pfeifferi Bres. Fitoterapia. 2003; 74: 177-80.

[15] Kabanov AS, Kosogova TA, Shishkina LN, Tepliakova TV, Skarnovich MO, Mazurkova NA, Puchkova LI, Malkova EM, Stavskiı̌ EA, Drozdov IG. Study of antiviral activity of extracts obtained from basidial fungi against Influenza viruses of different subtypes in experiments in vitro and in vivo. Zh Mikrobiol Epidemiol Immunobiology. 2011; (1): 40-3.

[16] Teplyakova TV, Bulychev LE, Kosogova TA, Ibragimova Zh B, Yurganova, IA, Kabanov AS, Puchkova LI, Bormotov NI, Bardasheva AV. Antiviral Activity of Extracts from Basidial Fungi with Respect to Orthopoxviruses. The Problems of Particularly Dangerous Infections. 2012; 3(113): 99-101.

[17] Rincão VP, Yamamoto KA, Ricardo NMPS, Soares SA, Meirelles LDP, Nozawa C, Linhares RE. Polysaccharide and extracts from Lentinula edodes: structural features and antiviral activity. Virol J. 2012; 9: 37-43.

[18] Zhu YC, Wang G, Yang XL, Luo DQ, Zhu QC, Peng T, Liu JK. Agrocybone, a novel bis-sesquiterpene with a spirodienone structure from basidiomycete Agrocybe salicacola. Tetrahedr Lett. 2010; 51: 3443-5.

[19] Tochikura TS, Nakashima H, Hirose K, Yamamoto N. A Biological Response Modifier, PSK, Inhibits Human Immunodeficiency Virus Infection in Vitro. Biochem. Biophys. Research Comm. 1987; 148: 72633.

[20] Lorenzen K, Anke T. Basidiomycetes as a Source for New Bioactive Natural Products. Current Organic Chemistry. 1998; 2: 329-64.

[21] Stamets P. MycoMedicinals. An Informational Treatise on Mushrooms. Olympia, WA: MycoMedia Productions. 2002.

[22] Teplyakova TV, Puchkova LI, Kosogova TA, Bulychev LE, Shishkina LN, Mazurkova N A, Gashnikova NM, Balakhnin SM, Kabanov AS, Kazachinskaya EI, Afonina VS. A Melanin-Based Antiviral Drug. RU Patent 2480227 C2, filed July 01, 2011, and issued April 27, 2013.

[23] Ling JY, Sun YJ, Zhang H, Lv P, Zhang CK. Measurement of cordycepin and adenosine in stroma of Cordyceps sp. by capillary zone electrophoresis (CZE). Journal of bioscience and bioengineering. 2002; 94(4): 371- 374.

[24] Cunningham KG, Manson W, Spring FS, Hutchinson SA. Cordycepin, a metabolic product isolated from cultures of Cordyceps militaris (Linn.) Link. Nature 1950; 166(4231): p.949.

[25] Das SK, Masuda M, Sakurai A and Sakakibara M. Medicinal uses of the mushroom Cordyceps militaris: current state and prospects. Fitoterapia. 2010; 81(8):961- 968.

[26] Tuli HS, Sharma AK, Sandhu SS, Kashyap D. Cordycepin: a bioactive metabolite with therapeutic potential. Life Sciences. 2013; 93(23): 863-869.

[27] Yong T, Chen S, Xie Y, Chen D, Su J, Shuai O, Jiao C, Zuo D. Cordycepin, a characteristic bioactive constituent in Cordyceps militaris, ameliorates hyperuricemia through URAT1 in hyperuricemic mice. Frontiers in microbiology. 2018; 9: 58.

[28] Glazer RI, Kuo JF. Inhibitory effects of cordycepin on cyclic nucleotide-dependent and cyclic nucleotideindependent protein kinases. Biochemical Pharmacology. 1977; 26(14): 1287-1290.

[29] Jin ML, Park SY, Kim YH, Park G, Son HJ, Lee SJ. Suppression of $\alpha$-MSH and IBMX-induced melanogenesis by cordycepin via inhibition of CREB and MITF, and activation of PI3K/Akt and ERKdependent mechanisms. International journal of molecular medicine. 2012; 29(1): 119-124.

[30] Mahy BW, Cox NJ, Armstrong SJ, Barry RD. Multiplication of influenza virus in the presence of cordycepin, an inhibitor of cellular RNA synthesis. Nature: New biology. 1973; 243(127):172-174. 
[31] Pridgen CL. Influenza virus RNA's in the cytoplasm of chicken embryo cells treated with 3'deoxyadenosine. Journal of virology. 1976; 18(1): 356-360.

[32] Muller WE, Weiler BE, Charubala R, Pfleiderer W, Leserman L, Sobol RW, Suhadolnik RJ, Schroder HC. Cordycepin analogues of 2',5'-oligoadenylate inhibit human immunodeficiency virus infection via inhibition of reverse transcriptase. Biochemistry. 1991; 30(8):2027-2033.

[33] Doetsch PW, Suhadolnik RJ, Sawada Y, Mosca JD, Flick MB, Reichenbach NL, Dang AQ, Wu JM, Charubala R, Pfleiderer W, Henderson EE. Core (2'-5') oligoadenylate and the cordycepin analog: inhibitors of Epstein--Barr virus-induced transformation of human lymphocytes in the absence of interferon. Proceedings of the National Academy of Sciences of the United States of America. 1981; 78(11): 66996703.

[34] Ryu E, Son M, Lee M, Lee K, Cho JY, Cho S, Lee SK, Lee YM, Cho H, Sung GH, Kang H. Cordycepin is a novel chemical suppressor of Epstein-Barr virus replication. Oncoscience. 2014; 1(12): 866.

[35] Chanda SD, Banerjee A, Nandi S, Chakrabarti S, Sarkar MC. Cordycepin an Adenosine Analogue Executes Anti Rotaviral Effect by Stimulating Induction of Type I Interferon. J Virol Antivir Res. 2015; 4(2): p.2.

[36] White JL and Dawson WO. Effect of cordycepin triphosphate on in vitro RNA synthesis by plant viral replicases. Journal of virology. 1979; 29(2): 811-814.

[37] Hsu CL, Yen GC. Ganoderic acid and lucidenic acid (triterpenoid). In The Enzymes. Academic Press. 2014; 36: 33-56.

[38] Su CY, Shiao MS, Wang CT. Differential effects of Ganodermic acid S on the thromboxane A2-signaling pathways in human platelets. Biochemistry Pharmacology. 1999; 58: 587-595.

[39] Li CH, Chen PY, Chang UM, Kan LS, Fang WH, Tsai KS, Lin SB. Ganoderic acid X, a lanostanoid triterpene, inhibits topoisomerases and induces apoptosis of cancer cells. Life Science. 2005; 77: 252-265.

[40] Zhao HB, Wang SZ, He Qh, Yuan L, Chen AF, Lin ZB. Ganoderma total sterol (GS) and GS1 protect rat cerebral cortical neurons from hypoxia/reoxygenation injury. Life Science. 2005; 76: 1027-1037.

[41] Mizushina Y, Takahashi N, Hanashima L, Koshino H, Esumi Y, Uzawa J, Sugawara F, Sakaguchi K. Lucidenic acid $\mathrm{O}$ and lactone, new terpene inhibitors of eukaryotic DNA polymerases from a basidiomycete, Ganoderma lucidum. Bioorganic Medical Chemistry. 1999; 7: 2047- 2052.

[42] Sahar EM, Meselhy MR, Nakamura N, Tezuka Y, Hattori M, Kakiuchi N, Shimotohno K, Kawahata T, Otake T. Anti-Hiv-1 and anti-Hiv-1-protease substances from Ganoderma lucidum. Phytochemistry. 1998; 49: $1651-1657$.

[43] Li YQ, Wang SF. Anti-hepatitis B activities of ganoderic acid from Ganoderma lucidum. Biotechnology letters. 2006; 28(11): 837-841.

[44] El-Khateeb WA, Zaghlol GM, El-Garawani IM, Ahmed EF, Rateb ME, Moneim AE. Ganoderma applanatum secondary metabolites induced apoptosis through different pathways: In vivo and in vitro anticancer studies. Biomedicine \& Pharmacotherapy. 2018; 101: 264-277.

Citation: Waill A. Elkhateeb, et.al., (2019). Antiviral Potential of Mushrooms in the Light of their Biological Active Compounds. ARC Journal of Pharmaceutical Sciences (AJPS), 5(2), pp 45-49. DOI: http://dx.doi.org/ 10.20431/2455-1538.0502003

Copyright: (C) 2019 Authors. This is an open-access article distributed under the terms of the Creative Commons Attribution License, which permits unrestricted use, distribution, and reproduction in any medium, provided the original author and source are credited. 